\title{
Dominant sources of dietary carbon and nitrogen for shrimp reared in extensive rice-shrimp ponds
}

\author{
Michele A. Burford ${ }^{1}$, Nigel P. Preston ${ }^{1}$, Truong Hoang Minh ${ }^{2}$, \\ Tran Thi Tuyet $\mathrm{Hoa}^{2}$, Stuart E. Bunn ${ }^{3}$, Vanessa M. Fry ${ }^{3}$
}

${ }^{1}$ CSIRO Marine Research, PO Box 120, Cleveland, Queensland, 4163, Australia ${ }^{2}$ Can Tho University, Can Tho, Vietnam

${ }^{3}$ Centre for Riverine Landscapes, Griffith University, Nathan, Queensland, 4111, Australia

Address for correspondence:

Michele Burford, Centre for Riverine Landscapes, Griffith University, Nathan, Queensland 4111, Australia.

Ph. +61 73875 6723, Fax +61 738757615

Email: m.burford@griffith.edu.au 


\section{Abstract}

Stable isotope analysis was used to determine the sources of dietary nitrogen (N) and carbon (C) for shrimp during the rearing phase in extensive rice-shrimp ponds in My Xuyen and Gia Rai districts, Vietnam. Farm-made feed was added as a food source in shrimp ponds in My Xuyen district, and based on stable isotope analyses, was generally a poor dietary source. The commercial formulated feed used in Gia Rai also appeared to contribute little directly to the nutritional needs of the shrimp. In contrast, the natural biota in all ponds appeared to contribute substantially. In particular, biota from beam trawls and benthic organic matter were the most likely sources of nutrition in My Xuyen ponds while benthic organic matter was the main source in Gia Rai ponds. $\delta^{15} \mathrm{~N}$ ratios in the natural biota in My Xuyen farms decreased over the growing season, suggesting increased $\mathrm{N}$ fixation; in the case of the benthic organic matter reaching values as low as $1 \%$. This suggests $\mathrm{N}$-limitation in the ponds and that natural biota become increasingly dependent on $\mathrm{N}$ fixed by algae and/or other microorganisms. There is the potential to promote the growth of the plankton and hence, the other natural biota, by the judicious addition of fertilizer.

\section{Introduction}

In saline affected areas of the Mekong Delta, Vietnam, the traditional wet-season rice crop is often supplemented with a dry-season crop of extensively farmed shrimp when salt water intrudes into the waterways (Tran, Dung \& Brennan 1999). The adoption of shrimp as a second crop in the dry season has resulted in significant income gains for some farmers (Tran et al. 1999; Brennan, Clayton \& Tran 2000). In 2000, 10,000 t of shrimp 
were produced from 40,000 ha of rice-shrimp farms in Vietnam (Brennan, Preston, Clayton \& Tran 2002).

In the rice-shrimp system, postlarval shrimp are recruited into the ponds through water exchange from nearby canals. Additionally, ponds are often stocked with hatchery-reared Penaeus monodon (Fabricius). Ponds contain one or more platforms for growing rice, surrounded by a deeper channel for rearing shrimp. Farmers use a variety of different feeding practices and diets for the shrimp that range from relying on the natural biota as the only food source, to feeding with farm-made formulations, or feeding with more expensive commercial feeds. A recent economic analysis of representative rice-shrimp farms has indicated that the addition of farm-made feeds, containing the main ingredients of rice and rice bran, has had little impact on production (Brennan et al. 2000). It may be that the dietary requirements of the shrimp are being met by natural pond biota rather than the farm-made feed; however the role of natural biota is poorly understood.

Measurement of stable isotope ratios in food sources and consumers may be used to determine the importance of different food sources to prawn nutrition (Gearing 1991; Shearer \& Kohl 1993). $\delta^{15} \mathrm{~N}$-nitrogen and $\delta^{13} \mathrm{C}$-carbon ratios are most commonly used. The stable isotope signature of a consumer reflects the isotopic signatures of material assimilated and provides an integration of feeding over time (Peterson \& Fry 1987). Stable isotope analysis has proved particularly effective in the study of aquatic food webs where there are often marked differences in the isotope signatures of the major primary sources (e.g. Boon \& Bunn 1994; Loneragan, Bunn \& Kellaway 1997). 
In this study, we used stable isotope analysis to determine the sources of dietary $\mathrm{N}$ and $\mathrm{C}$ for shrimp grown in rice-shrimp ponds, particularly comparing the role of the farm-made and commercial feeds, and the natural biota.

\section{Materials and methods}

Study sites

The study was conducted at three rice-shrimp farms, each with one pond, in the My Xuyen district in 1998, and three rice-shrimp farms, each with one pond, in the Gia Rai district of the Mekong Delta, Vietnam in 2000 (Fig. 1). The size of the ponds varied from 1 to 1.4 ha (Table 1), and all farms in the My Xuyen district had a central platform area (80\% of the total pond area, water depth approximately $20 \mathrm{~cm}$ ), where a wet season rice crop was grown prior to a dry season shrimp crop, and a ditch around the perimeter of the platform (water depth approximately $1 \mathrm{~m}$ ). At Gia Rai, ponds had four platforms surrounded by deeper water.

Prior to stocking, ponds were prepared by removal of sedimented material in the ditches, drying the platforms, liming the entire pond and killing predators with rotenone. The ponds were stocked with hatchery reared Penaeus monodon postlarvae (mean total length, $18 \mathrm{~mm}$ ) at stocking densities between 1 and 3 animals $\mathrm{m}^{-2}$ (Table 1 ). Other shrimp species (e.g. Penaeus merguiensis (de Man)) were also present in some ponds in lesser numbers, having been recruited from the river during routine water exchanges. These shrimp are referred to as ‘wild shrimp'. After a period of 9 to 16 weeks, all shrimp were harvested from ponds, and total weights for each pond were recorded (Table 1). 
There were two main types of feed added to the ponds: commercial and farm-made. The farm-made feed was made by combining fishmeal and ricebran, mixing in cooked rice to form a paste, then forcing the feed through a mincer. The extruded paste was air dried. Later in the season, cornmeal was also added to this feed prior to mixing with cooked rice and forming a paste. Fishmeal was only used in the feed at the start of the season. The quality and type of feed varied from pond to pond (Table 1). There were two brands of commercial formulated feeds; one used in at My Xuyen farms (CF1) and one used at Gia Rai in two of the three farms (CF2). One of the ponds at Gia Rai had no added feeds. In the My Xuyen farms, CF1 was used only for a short period early in the season.

\section{Sampling and analysis}

Ponds were sampled at three occasions during the shrimp growth season: one (early), two (mid) and three (late) months after stocking in My Xuyen ponds; and one (early) and two (mid) months after stocking in Gia Rai ponds. After this time the trial at Gia Rai was terminated due to an outbreak of White Spot Syndrome Virus in the shrimp. Triplicate samples were taken of the natural biota, feed and shrimp in each of the three ponds early, mid and late season for stable isotope analysis. The seston was sampled using a plankton net (mesh size $100 \mu \mathrm{m}$ ) towed $20 \mathrm{~m}$ in the ditch. The tow was repeated twice. The combined samples from the tows were washed from the net into containers, and stored on ice until returned to the laboratory. Triplicate samples were taken. Beam trawl samples were taken by towing a trawl (mesh size $1000 \mu \mathrm{m}$ ) across both the ditch and the platform. The tow was repeated twice. The biota from both tows were picked out, and stored in a container on ice. Triplicate samples were taken. Samples of benthic organic matter were taken with a core from the sediments at three sites in the ditch and combined, and four sites 
on the platform and combined. Triplicate samples of sediment from both the ditch and the platform were taken. Samples were also taken of the commercial feeds, farm-made feeds, $P$. monodon and the wild shrimp from each farm for isotope analysis.

All feed, shrimp and biota samples were then dried at $60^{\circ} \mathrm{C}$ in the laboratory, ground with a mortar and pestle, and stored until analyzed for stable nitrogen and carbon isotope ratios, and $\mathrm{N}$ and $\mathrm{C}$ content using an elemental analyzer (Eurovector 3000) and mass spectrometer (Micromass Isoprime). Three replicate samples were analysed for shrimp and biota. Ratios of ${ }^{13} \mathrm{C} /{ }^{12} \mathrm{C}$ and ${ }^{15} \mathrm{~N} /{ }^{14} \mathrm{~N}$ were expressed as the relative per mil (\%o) difference between the sample and conventional standards (PDB carbonate and $\mathrm{N}_{2}$ in air) where:

$$
\delta \mathrm{X}=\left(\mathrm{R}_{\text {sample }} / \mathrm{R}_{\text {standard }}-1\right) \times 1000(\%)
$$

Where $\mathrm{X}={ }^{13} \mathrm{C}$ or ${ }^{15} \mathrm{~N}$ and $\mathrm{R}={ }^{13} \mathrm{C} /{ }^{12} \mathrm{C}$ or ${ }^{15} \mathrm{~N} /{ }^{14} \mathrm{~N}$ (Peterson \& Fry , 1987). Measurement precision was approximately 0.1 and $0.2 \%$ for ${ }^{13} \mathrm{C} /{ }^{12} \mathrm{C}$ and ${ }^{15} \mathrm{~N} /{ }^{14} \mathrm{~N}$, respectively.

Water quality parameters were monitored in all ponds. Temperature and salinity were monitored at three sites on the platform and three sites in the ditch early in the morning and mid-afternoon each day using a datalogger (Yeokal). In the case of the ditch, readings were taken at the top and bottom of the water column. Water samples were also taken for chlorophyll $a$ and total suspended solids (TSS) analysis at the same time as stable isotope samples. Water for chlorophyll $a$ analysis was filtered through glass fibre filters (GF/F), extracted in acetone and measured spectrophotometrically (Jeffrey \& Welshmeyer 
1997). For TSS analysis, water was filtered onto pre-weighed, pre-combusted glass fibre filters $(\mathrm{GF} / \mathrm{F})$, dried at $60^{\circ} \mathrm{C}$ for $24 \mathrm{~h}$, then reweighed at room temperature.

\section{Results}

The shrimp survival and harvest values were similar in all three My Xuyen ponds with between 340 and $440 \mathrm{~kg}$ (mean individual weight $25.6 \mathrm{~g}$ ) being harvested from each farm (Table 1). All three farms used farm-made feeds with rice, ricebran, cornmeal and fishmeal but the ratio of ingredients and total amount added varied from farm to farm. Fishmeal was only used in the first month, cornmeal only towards the end of the season. Commercial feed (CF1) was only added early in the season. Food conversion ratios (FCR), calculated from the addition of farm-made and commercial feeds, ranged from 1.7 to 2.2 .

In contrast, shrimp survival and harvest values for Gia Rai farms were lower (19 to $160 \mathrm{~kg}$, mean individual weight $6.0,23.0$ and $22.6 \mathrm{~g}$ for farms 4,5 and 6 respectively) despite the higher stocking densities in two of the three ponds. The low values were due to an outbreak of white spot syndrome virus in the shrimp resulting in ponds being harvested midway through the growout season (Preston, N., pers. comm.). Prior to the viral outbreak, shrimp growth rates for the My Xuyen and Gia Rai farms were similar, i.e. 1.6 and 2.0 g week $^{-1}$ respectively. No farm-made feed was used in the Gia Rai farms but a commercial feed (CF2) was added to two of the three farms with FCRs ranging from 1.3 to 5.4. Farm 6, with the highest shrimp survival, had no feed addition and shrimp were reliant on the natural biota. 
Temperature and salinity in My Xuyen ponds ranged from 24.9 to $40.0^{\circ} \mathrm{C}$, and 4.8 to 17.5 respectively (Table 2). In Gia Rai ponds, temperatures were lower and the salinity was higher (23.3 to $33.0^{\circ} \mathrm{C}$, and 9.1 to 29.9 respectively). Chlorophyll $a$ concentrations were generally higher in Gia Rai ponds than My Xuyen ponds (6-46 and 1-29 $\mu \mathrm{g} \mathrm{l}^{-1}$ respectively) (Table 2). TSS concentrations were also higher in Gia Rai ponds than My Xuyen ponds (78.6 - 380.2 and 42.6 - $135.6 \mathrm{mg} \mathrm{l}^{-1}$ respectively).

Carbon:nitrogen $(\mathrm{C}: \mathrm{N})$ ratios in the seston and biota from beam trawls were above Redfield (1958) ratios and higher than the shrimp in the My Xuyen ponds early in the growth season (Fig. 2). By mid season, the $\mathrm{C}: \mathrm{N}$ ratios of beam trawl and seston samples had decreased, becoming closer to the $\mathrm{C}: \mathrm{N}$ ratios of shrimp. The $\mathrm{C}: \mathrm{N}$ ratios of biota from beam trawls remained low late in the growth season. In the Gia Rai ponds, the C:N ratios of the natural biota were low and similar to the shrimp throughout the growth season (Fig. 2).

There was little difference in the $\delta^{13} \mathrm{C}$ and $\delta^{15} \mathrm{~N}$ ratios of the potential food sources and shrimp between the three ponds at My Xuyen. Therefore, the data from all ponds was combined for each growth stage for ease of comparison between growth stages and farming districts. Early in the growth season the $\delta^{13} \mathrm{C}$ and $\delta^{15} \mathrm{~N}$ ratios of the beam trawl biota and the farm-made feed were similar to those of the shrimp while the isotope signatures of seston and the sediment were higher in the case of $\delta^{15} \mathrm{~N}$ and lower in the case of $\delta^{13} \mathrm{C}$ (Fig. 3). Differences in the formulations of the farm-made feed between farms are reflected in the $\delta^{13} \mathrm{C}$ and $\delta^{15} \mathrm{~N}$ ratios. By mid season, the farm-made feed and seston had lower $\delta^{13} \mathrm{C}$ ratios compared with the shrimp while the beam trawl, filamentous algae and 
benthic organic matter had similar ratios. $\delta^{15} \mathrm{~N}$ ratios for these food sources were all lower by 3 to 7 \% than for the shrimp. The commercial feed, CF1 had similar isotopic signatures to the shrimp, although it was only added early in the growth season. The $\delta^{13} \mathrm{C}$ and $\delta^{15} \mathrm{~N}$ ratios of the potential food sources and shrimp remained much the same late in the growth season. The \%nitrogen in the farm-made feeds changed over the season from $6.2 \%$ early in the season, which was comparable with the commercial feed CF1 (6.3\%), decreasing to $3.2 \%$ by mid-season and $2.5 \%$ by the end of the season.

Early in the growth season in Gia Rai ponds, the benthic organic matter and seston had $\delta^{13} \mathrm{C}$ ratios similar to the shrimp while the commercial feed, CF2 and biota from beam trawls had higher $\delta^{13} \mathrm{C}$ ratios (Fig. 3). By mid season, there was little change with the exception of an increase in the $\delta^{13} \mathrm{C}$ ratio of seston. $\delta^{15} \mathrm{~N}$ ratios of benthic organic matter were 2 to $3 \%$ lower than for shrimp. The \%nitrogen in CF2 feed was 6.3\%.

If a primary source of carbon is important to the aquatic food web, then the spatial and temporal variability in $\delta^{13} \mathrm{C}$ values of consumers should track the observed variability of the source. The $\delta^{13} \mathrm{C}$ ratios of $P$. monodon and wild shrimp were compared with the $\delta^{13} \mathrm{C}$ ratios of potential food sources for all farms (Fig. 4). There was a significant correlation between the $\delta^{13} \mathrm{C}$ ratios of the shrimp and the biota from beam trawls (Fig. 4 a, $\mathrm{R}^{2}=0.58$, $P<0.001)$. There was also a significant correlation between benthic organic matter and shrimp (Fig. 4 c, $\mathrm{R}^{2}=0.86, P<0.001$ ). In contrast, there was no correlation between the added feed sources or seston and the shrimp (Figs. 4 b, d). 
There was a trend of decreasing $\delta^{15} \mathrm{~N}$ ratios in the pond biota over the growout season in both My Xuyen and Gia Rai ponds (Figs. 5 a, b). This was most pronounced in the benthic matter where values decreased to between 1 and $2 \%$.

\section{Discussion}

Farm-made feed used in My Xuyen ponds was highly variable in quality and composition and, in general, had a sufficiently different $\delta^{13} \mathrm{C}$ ratio to the shrimp to suggest that it was not an important source of carbon for the shrimp. Additionally, the $\delta^{13} \mathrm{C}$ and $\delta^{15} \mathrm{~N}$ ratios of the shrimp did not change markedly during the season, despite the large fluctuations in ratios in the farm-made feed, and the reduction in the \%nitrogen in the feed below levels generally considered necessary to meet the protein requirements of the shrimp (Guillaume 1997). This reduction is likely to be due to the removal of fishmeal, which has a high protein level, from the ingredients early in the season. Similarly, the commercial feed used in Gia Rai ponds did not appear to be an important nutritional source since the shrimp were too $\delta^{13} \mathrm{C}$ and $\delta^{15} \mathrm{~N}$ depleted compared with the feed. At the farm with no feed addition, there was no obvious difference in $\delta^{13} \mathrm{C}$ and $\delta^{15} \mathrm{~N}$ ratios. Given this finding, it is not surprising that an earlier economic analysis of rice-shrimp ponds found that at this low level of stocking density, farm-made feeds had little impact on shrimp production (Brennan et al. 2000).

Much of the organic matter added as farm-made or commercial feed is likely to have entered a microbial dead-end (e.g. Lewis, Hamilton, Rodríguez, Saunders \& Lasi 2001) or been discharged into adjacent waterways during water exchange episodes. Promotion of high bacterial respiration may lead to low dissolved oxygen in ponds with 
little direct transfer of biomass to higher order consumers. A previous study in extensive shrimp ponds showed that a high proportion of the $\mathrm{N}$ and $\mathrm{C}$ inputs were ultimately discharged from ponds (Alongi, Johnston \& Xuan 2000). Eutrophication of coastal waters caused by shrimp farming is of increasing concern globally and has the capacity to promote algal blooms, cause hypoxia, reduce biodiversity and negatively impact on fish nursery sites (Dierberg \& Kiattisimkul 1996; Páez-Osuna 2001). The use of farm-made or poor quality commercial feeds is, therefore, an inefficient farming practice and a potential contributor to coastal eutrophication.

The similarity of the $\delta^{13} \mathrm{C}$ isotopic ratios of the shrimp, benthic organic matter and biota from beam trawls, suggests that the natural biota were an important carbon source for the shrimp in all My Xuyen ponds. Assuming a $3 \%$ increase in the $\delta^{15} \mathrm{~N}$ ratio with trophic level (Shearer \& Kohl 1993), benthic matter and biota from beam trawls appear to be the main nitrogen sources for shrimp nutrition. Filamentous algae may also have contributed to shrimp nutrition, based on the $\delta^{13} \mathrm{C}$ and $\delta^{15} \mathrm{~N}$ ratios in mid-growth season while seston did not appear to contribute substantially to the $\mathrm{N}$ and $\mathrm{C}$ requirements of the shrimp.

In contrast, shrimp in Gia Rai ponds were more ${ }^{13} \mathrm{C}$ depleted than those in My Xuyen ponds and shrimp appeared to be deriving carbon from the benthic matter but not significantly from the beam trawl biota or seston. Assuming a $3 \%$ increase in the $\delta^{15} \mathrm{~N}$ ratio with trophic level, the benthic organic matter may have provided at least some of the nitrogen requirements of the shrimp. Other studies have shown that postlarval and juvenile shrimp derive much of their nutrition from benthic sources (Newell, Marshall, Sasekumar \& Chong 1995; Dittel, Epifanio, Cifuentes \& Kirchman 1997). Studies in extensive 
shrimp ponds have shown that the zooplankton and macrobenthos densities can be sufficient to support low stocking densities of shrimp (Johnston, Lourey, Tien, Luu \& Xuan 2002).

The highly turbid waters, as indicated by the high TSS concentrations, are likely to have limited the growth of primary producers in the rice-shrimp ponds, particularly in the ditches. This is reflected in the low chlorophyll $a$ concentrations in the pond. Studies in extensive shrimp ponds have found low primary productivity, as a result of the high turbidity reducing light availability, high respiration rates and oxygen stress (Alongi, Dixon, Johnston, Tien \& Xuan 1999; Johnston et al. 2002). Turbid water enters the pond system during water exchanges and the resulting build-up of sediments is environmentally and ecologically unsustainable (Brennan et al. 2002). However, reducing the turbidity of the water may result in other water quality problems, e.g. excessive growth of benthic filamentous algae can cause hypoxia and fouling the gills of shrimp thereby negatively affecting shrimp growth and survival

The decrease in $\delta^{15} \mathrm{~N}$ ratios in the natural biota throughout the season in My Xuyen ponds suggests that $\mathrm{N}$ fixation is an important process in providing $\mathrm{N}$ to the natural biota. In the case of the shrimp $\mathrm{N}$ isotope signatures, the observed decline is counter to an expected increase in $\delta^{15} \mathrm{~N}$ ratios as shrimp grow and feed at a higher trophic position (Peterson \& Fry, 1987). $\delta^{15} \mathrm{~N}$ ratios in the benthic organic matter at the end of the season were close to 1\%o, consistent with the presence of N fixing algae (Yoshioka, Wada \& Hayashi 1994). This contrasts with extensive shrimp ponds where $\mathrm{N}$ fixation rates were low (Alongi et al. 2000). However these ponds lacked a central platform with high light availability and rice 
plant detritus creating a high surface area for epiphytic growth. The addition of $\mathrm{N}$ fertilizer early in the growth season may therefore be beneficial in promoting the growth of the natural biota. However, care must be taken to ensure that over-fertilizing does not occur as this will increase coastal eutrophication and may promote blooms of nuisance algae, e.g. filamentous algae, in the ponds.

The findings from this study can be summarized in a conceptual model of the major pathways of carbon and nitrogen flow that highlights the likely differences between shrimp ponds in the two districts (Fig. 6). In My Xuyen, biota from beam trawls contributed directly to shrimp nutrition while benthic organic matter and filamentous algae contributed both directly and indirectly. Farm-made feeds did not contribute significantly to shrimp nutrition and the main source of nitrogen was from fixation of atmospheric nitrogen. In Gia Rai ponds, benthic matter and filamentous algae contributed more directly to shrimp nutrition than in My Xuyen ponds with less contribution from beam trawl biota.

Commercial feeds did not contribute directly to shrimp nutrition, however they may have provided a nutritional source for beam trawl biota, based on the similarity of the ${ }^{13} \mathrm{C}$ ratios for the commercial feed and biota. As in My Xuyen ponds, much of the nitrogen was supplied by nitrogen fixers. It is not clear to what degree differences in water quality parameters between the two districts, namely temperature, salinity and TSS, affected the flows of nitrogen and carbon within the pond systems, or shrimp production.

In conclusion, our study has shown that there is scope to improve dietary nitrogen and carbon sources for shrimp in rice-shrimp ponds. The dominant role of the natural biota in these low intensity systems may be further enhanced with the judicious addition of 
fertilizers to stimulate productivity. Future work is warranted to ascertain the trophic pathways of $\mathrm{N}$ and $\mathrm{C}$ to determine where the natural biota are gaining their nutrition, and ultimately the source of nutrients for the shrimp. Additionally, this study did not quantify the $\delta^{15} \mathrm{~N}$ and $\delta^{13} \mathrm{C}$ ratios in the phytoplankton or algae on the rice stalks or ditch walls. They may also be significant sites of algal production that ultimately underpin the food web supporting shrimp. The benefits of the added feed were highly variable and seem to be dependent on the feed formulation. As farmers move towards intensification, the use of higher quality feeds may improve yields as well as minimize nutrient wastes that are ultimately discharged into coastal waterways. It is likely that the water stability of the airdried feeds was a key issue in the poor utilization of feed. Additionally the substantial reduction in \%nitrogen in the feed over the season suggests that it would not supply the protein requirements of the shrimp. These results coupled with those of Brennan et al. (2000) suggest that there is little economic value in the production of low quality farmmade feeds for extensive rice-shrimp farming in Vietnam. 


\section{Acknowledgements}

We wish to thank the farmers in My Xuyen and Gia Rai districts, Vietnam that took part in the study. Danielle Johnston and Frank Coman provided constructive criticism of this paper. This work was funded by the Australian Centre for International Agricultural Research (ACIAR) and CSIRO Marine Research. 


\section{References}

Alongi D.M., Dixon P., Johnston D.J., Tuan D.V. \& Xuan T.T. (1999) Pelagic processes in extensive shrimp ponds of the Mekong delta, Vietnam. Aquaculture 175, 121-141.

Alongi D.M., Johnston D.J. \& Xuan T.T. (2000) C and N budgets in shrimp ponds of extensive mixed shrimp-mangrove forestry farms in the Mekong delta, Vietnam. Aquaculture Research 31, 387-399.

Boon P.I. \& Bunn S.E. (1994) Variations in the stable-isotope composition of aquatic plants and their implication for food-web analysis. Aquatic Botany 48, 99-108.

Brennan D.C., Clayton H. \& Tran T.B. (2000) Economic characteristics of rice shrimp farms in the Mekong Delta, Vietnam. Aquaculture Economics and Management 4, 1-13.

Brennan D., Preston N., Clayton H. \& Tran T.B. (2002) An evaluation of Rice-Shrimp Farming Systems in the Mekong Delta. Report prepared under the World Bank, NACA, WWF and FAO Consortium Program on Shrimp Farming and the Environment. Work in Progress for Public Discussion. Published by the Consortium.

http://192.150.250.134/ShrimpWebsite/Case/Vietnam/FinalVietnam.pdf

Dierberg F.E. \& Kiattisimkul W. (1996) Issues, impacts, and implications of shrimp aquaculture in Thailand. Environmental Management 20, 649-666.

Dittel A.I., Epifanio C.E., Cifuentes L.A. \& Kirchman D.L. (1997) C and N sources for shrimp postlarvae fed natural diets from a tropical mangrove system. Estuarine, Coastal and Shelf Science 45, 629-637.

Gearing J.N. (1991) The study of diet and trophic relationships through natural abundance ${ }^{13} \mathrm{C}$. In: Carbon Isotope Techniques, Coleman D.C., Fry B. (Eds.), pp. 201-218. Academic Press, San Diego. 
Guillaume J. (1997) Protein and amino acids. In: Crustacean Nutrition. Advances in World Aquaculture, Vol. 6., D'Abramo L.R., Conklin D.E., Akiyama D.M. (Eds.), pp. 26-50. World Aquaculture Society, Baton Rouge, Louisiana.

Jeffrey S.W. \& Welshmeyer N.A. (1997) Spectrophotometric and fluorometric equations in common use in oceanography. In: Phytoplankton Pigments in Oceanography, Monographs on Oceanographic Methodology No. 10 (ed. by S.W. Jeffrey, R.F.C. Mantoura \& S.W. Wright), pp 597-615, UNESCO Publishing, Paris.

Johnston D., Lourey M., Tien D.V., Luu T.T. \& Xuan T.T. (2002) Water quality and plankton densities in mixed shrimp-mangrove forestry farming systems in Vietnam. Aquaculture Research, 33, 1-14.

Lewis W.M., Hamilton S.K., Rodríguez M.A., Saunders III J.F. \& Lasi M.A. (2001) Food web analysis of the Orinoco floodplain based on production estimates and stable isotope data. Journal of the North American Benthological Society, 20, 241-254.

Loneragan, N.R., Bunn, S.E. \& Kellaway, D.M. (1997) Are mangrove and seagrasses sources of organic carbon for penaeid prawns in a tropical Australian estuary?: A multiple stable isotope study. Marine Biology 130, 289-300.

Newell R.I.E., Marshall N., Sasekumar A. \& Chong V.C. (1995) Relative importance of benthic microalgae, phytoplankton, and mangroves as sources of nutrition for penaeid prawns and other coastal invertebrates from Malaysia. Marine Biology, 123, 595-606.

Páez-Osuna F. (2001) The environmental impact of shrimp aquaculture: Causes, effects and mitigating alternatives. Environmental Management 28, 131-140.

Peterson B.J. \& Fry B. (1987) Stable isotopes in ecosystem studies. Annual Reviews of Ecological Systematics 18, 293-320.

Redfield A.C. (1958) The biological control of chemical factors in the environment. American Science 46, 205-222. 
Shearer G.S. \& Kohl D.H. (1993) Natural abundance of ${ }^{15} \mathrm{~N}$ : Fractional contribution of two sources to a common sink and use of isotope discrimination. In: Nitrogen Isotope Techniques (ed. by R. Knowles \& T.H. Blackburn), pp. 89-125. Academic Press, San Diego, USA.

Tran T.B., Dung L.C. \& Brennan D.C. (1999) Environmental costs of shrimp culture in the rice growing regions of the Mekong Delta. Aquaculture Economics and Management 3, $31-43$.

Yoshioka T., Wada E. \& Hayashi H. (1994) A stable isotope study on seasonal food web dynamics in a eutrophic lake. Ecology 75, 835-846. 
Table 1: Shrimp and feed data for farms in My Xuyen and Gia Rai districts. Shrimp harvest includes $P$. monodon and wild shrimp. FCR $=$ food conversion ratio.

\begin{tabular}{|c|c|c|c|c|c|c|}
\hline & \multicolumn{3}{|c|}{ My Xuyen } & \multicolumn{2}{|c|}{ Gia Rai } & \multirow[b]{2}{*}{ Farm 6} \\
\hline & Farm 1 & Farm 2 & Farm 3 & Farm 4 & Farm 5 & \\
\hline Pond size (ha) & 1 & 1.3 & 1 & 1 & 1.2 & 1.4 \\
\hline $\begin{array}{l}P . \text { monodon stocking } \\
\text { density }\left(\mathrm{m}^{-2}\right)\end{array}$ & 1.6 & 1.6 & 1.6 & 3 & 3 & 1 \\
\hline Grow-out period (wk) & 16 & 16 & 16 & 9 & 9 & 9 \\
\hline Shrimp harvest $\left(\mathrm{kg} \mathrm{ha}^{-1}\right)$ & 340 & 400 & 440 & 19 & 160 & 130 \\
\hline P. monodon survival (\%) & 83 & 87 & 94 & 10 & 23 & 57 \\
\hline FCR & 2.1 & 1.7 & 2.2 & 5.4 & 1.3 & - \\
\hline \multicolumn{7}{|l|}{ Feed } \\
\hline \multicolumn{7}{|l|}{ Commercial feed (kg) } \\
\hline CF1 & 67 & 67 & 75 & - & - & - \\
\hline CF2 & - & - & - & 102 & 206 & - \\
\hline Total added & 67 & 67 & 75 & 102 & 206 & - \\
\hline \multicolumn{7}{|c|}{ Ingredients in farm-made feed (kg) } \\
\hline Rice & 400 & 400 & 300 & - & - & - \\
\hline Ricebran & 125 & 125 & 150 & - & - & - \\
\hline Cornmeal & 50 & 50 & 27 & - & - & - \\
\hline Fishmeal & 60 & 60 & 400 & - & - & - \\
\hline Total added & 635 & 635 & 877 & & & \\
\hline
\end{tabular}


Table 2: Ranges in temperature $\left({ }^{\circ} \mathrm{C}\right)$, salinity chlorophyll $a\left(\mu \mathrm{g} \mathrm{l}^{-1}\right)$ and total suspended solids (TSS) (mg $\left.{ }^{-1}\right)$ concentrations at three farms in the My Xuyen district (1997/1998) and three farms in the Gia Rai district (2000).

\begin{tabular}{ccccc}
\hline & $\begin{array}{c}\text { Temperature } \\
\left({ }^{\circ} \mathrm{C}\right)\end{array}$ & Salinity & $\begin{array}{c}\text { Chlorophyll } a \\
\left(\mu \mathrm{g} \mathrm{l}^{-1}\right)\end{array}$ & $\begin{array}{c}\text { TSS } \\
\left(\mathrm{mg} \mathrm{l}^{-1}\right)\end{array}$ \\
\hline My Xuyen & & & $3-14$ & \\
Farm 1 & $24.9-38.6$ & $5.9-17.4$ & $1-29$ & $51.7-91.2$ \\
Farm 2 & $25.0-40.0$ & $6.0-17.5$ & $3-19$ & $44.8-135.6$ \\
Farm 3 & $26.6-39.9$ & $4.8-16.2$ & & \\
Gia Rai & & & $20-46$ & $131.1-380.2$ \\
Farm 1 & $23.6-33.0$ & $9.2-26.9$ & $7-29$ & $81.6-192.4$ \\
Farm 2 & $23.3-32.2$ & $14.1-29.9$ & $6-41$ & $78.6-209.3$ \\
Farm 3 & $23.8-32.4$ & $9.1-28.7$ & & \\
\hline
\end{tabular}


Figure legend

Figure 1. Map of the study sites in the Mekong Delta, Vietnam. Farms were in the My Xuyen and Gia Rai regions.

Figure 2. Percent carbon and nitrogen in shrimp and natural biota in (a) early, (b) middle and (c) late growth season ponds in My Xuyen district, and (d) combined early and middle growth season ponds in Gia Rai district in Vietnam. Solid line is the Redfield (1958) ratio. BOM = benthic organic matter.

Figure 3. $\delta^{13} \mathrm{C}$ and $\delta^{15} \mathrm{~N}$ values (\%o) of shrimp, feed and natural biota in (a) early, (b) middle and (c) late growth season ponds in My Xuyen district, and (a) early and (b) middle growth season ponds in Gia Rai district in Vietnam. BOM = benthic organic matter.

Figure 4. A comparison of $\delta^{13} \mathrm{C}$ values (\%o) of shrimp and food sources; (a) beam trawl, (b) farm-made and commercial feeds, (c) benthic organic matter, and (d) seston in all ponds in My Xuyen and Gia Rai districts.

Figure 5. $\delta^{15} \mathrm{~N}$ values (\%o) of the natural biota and shrimp in ponds early, middle and late in the growth season in (a) My Xuyen and (b) Gia Rai districts. BOM = benthic organic matter.

Figure 6. Conceptual diagram of the flow of nitrogen and carbon through ponds in My Xuyen and Gia Rai districts. BOM = benthic organic matter. 


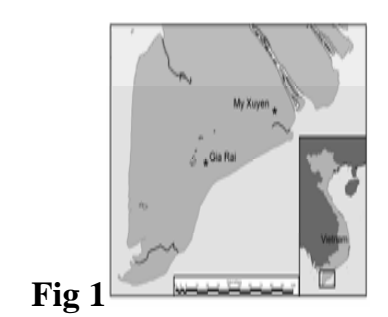


My Xuyen
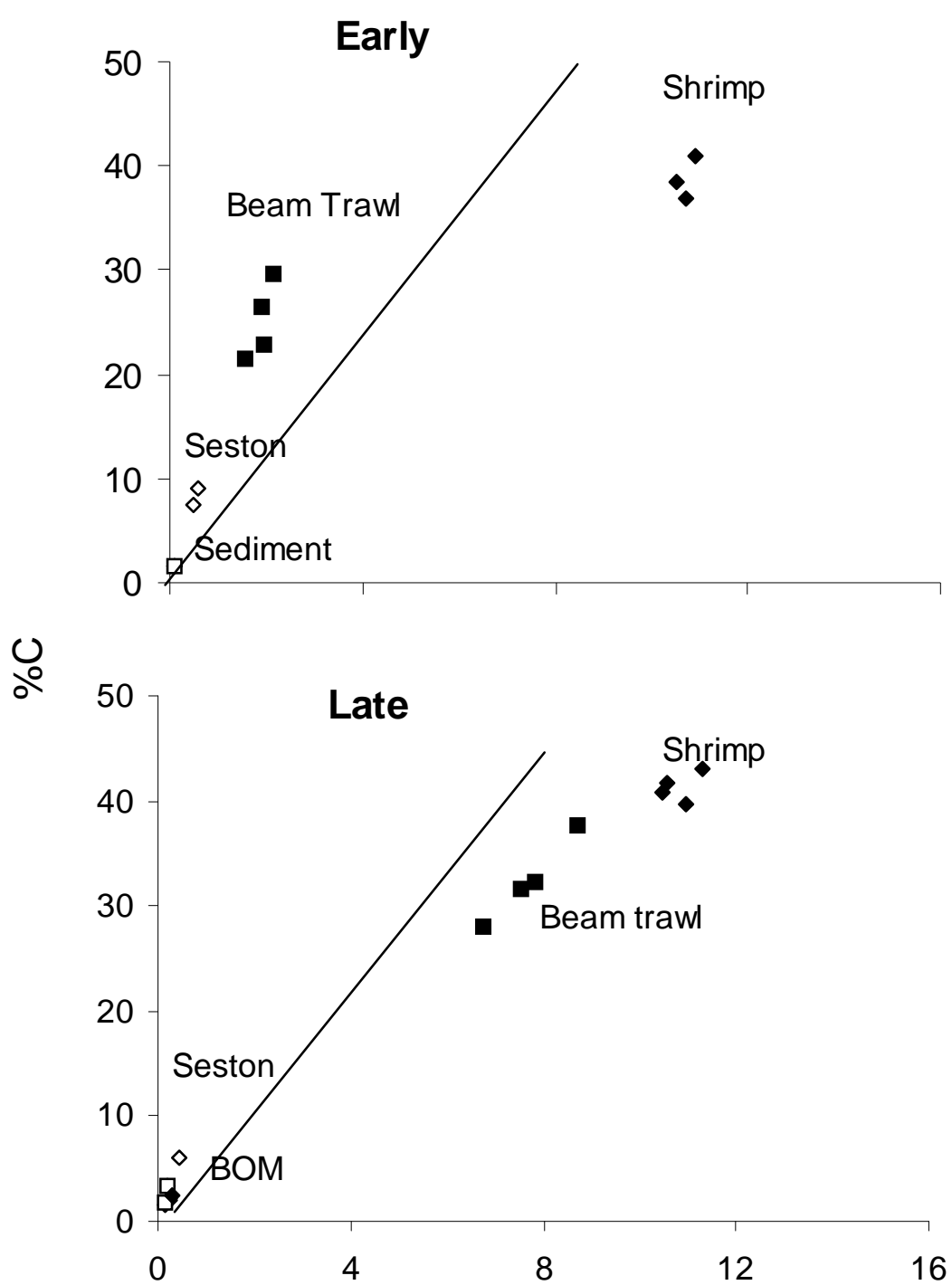
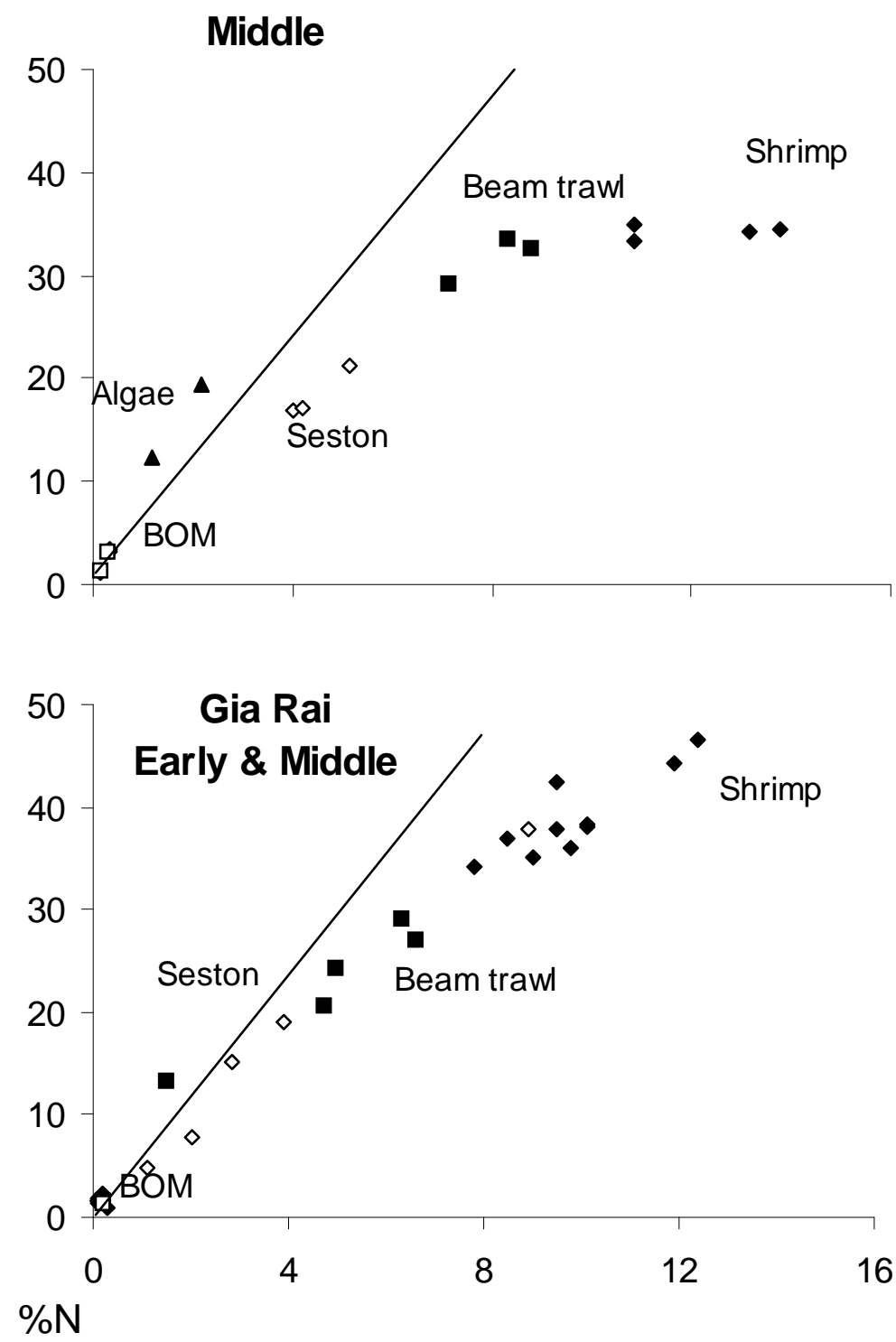
My Xuyen
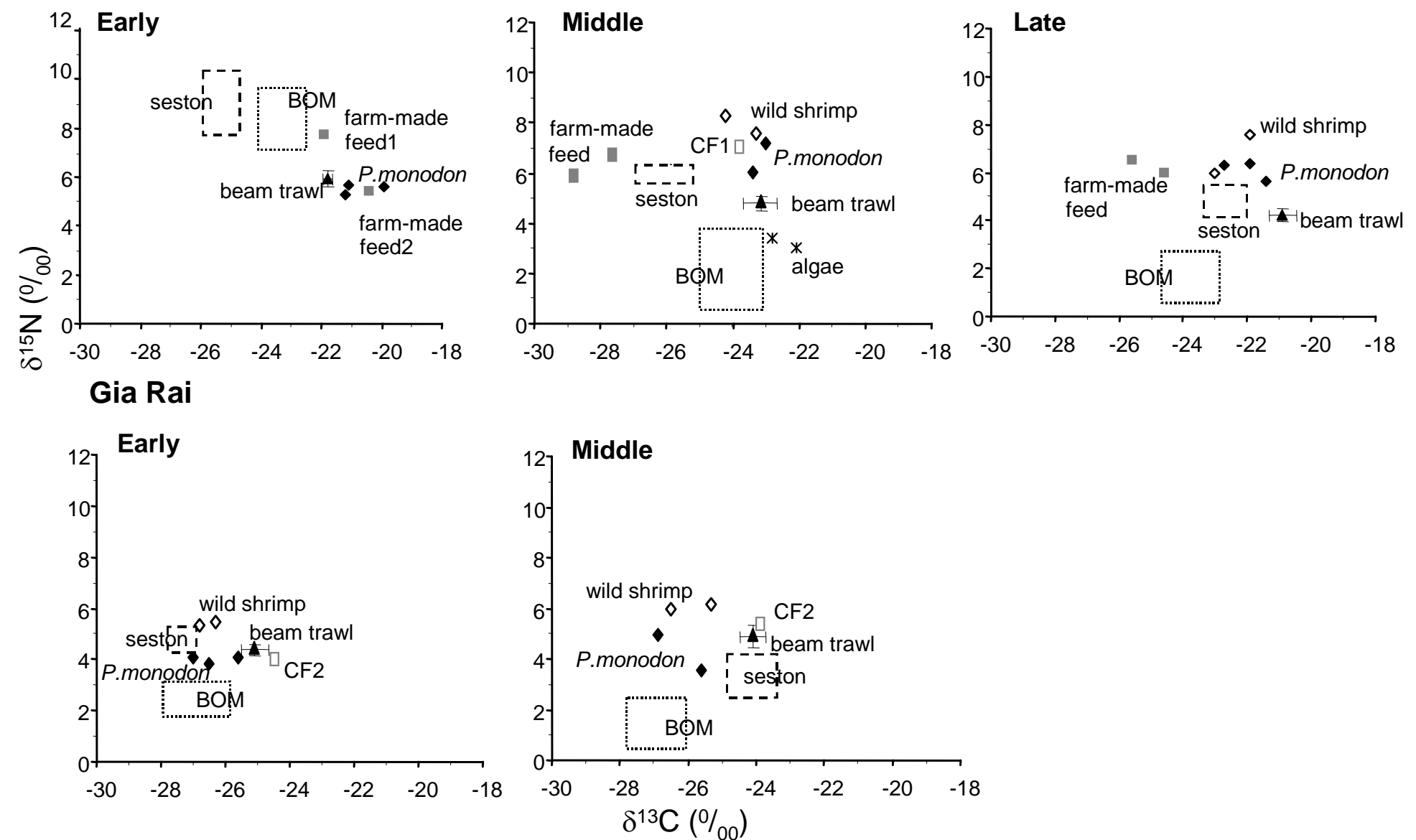

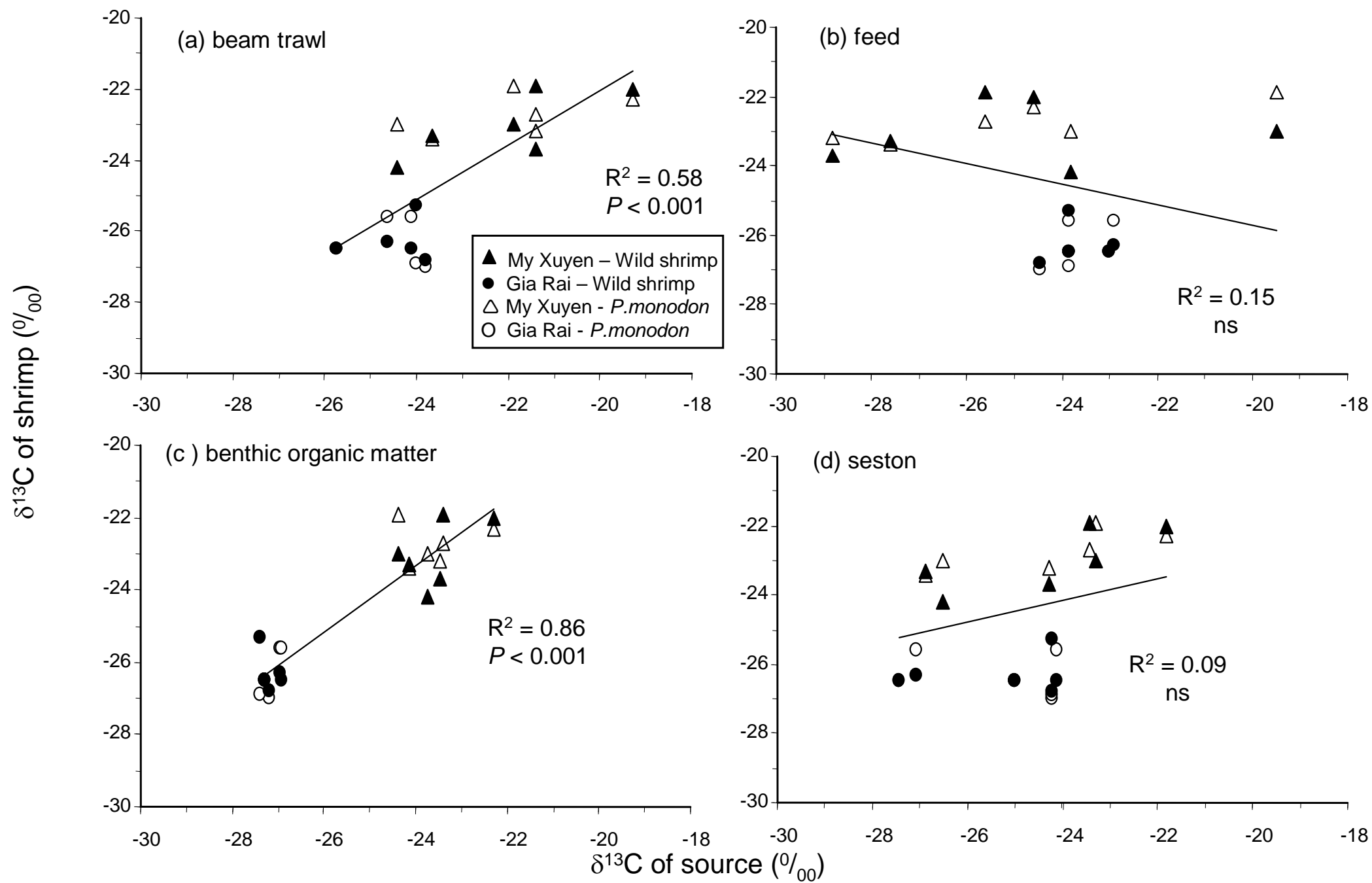


\section{Vietnam time scale data}
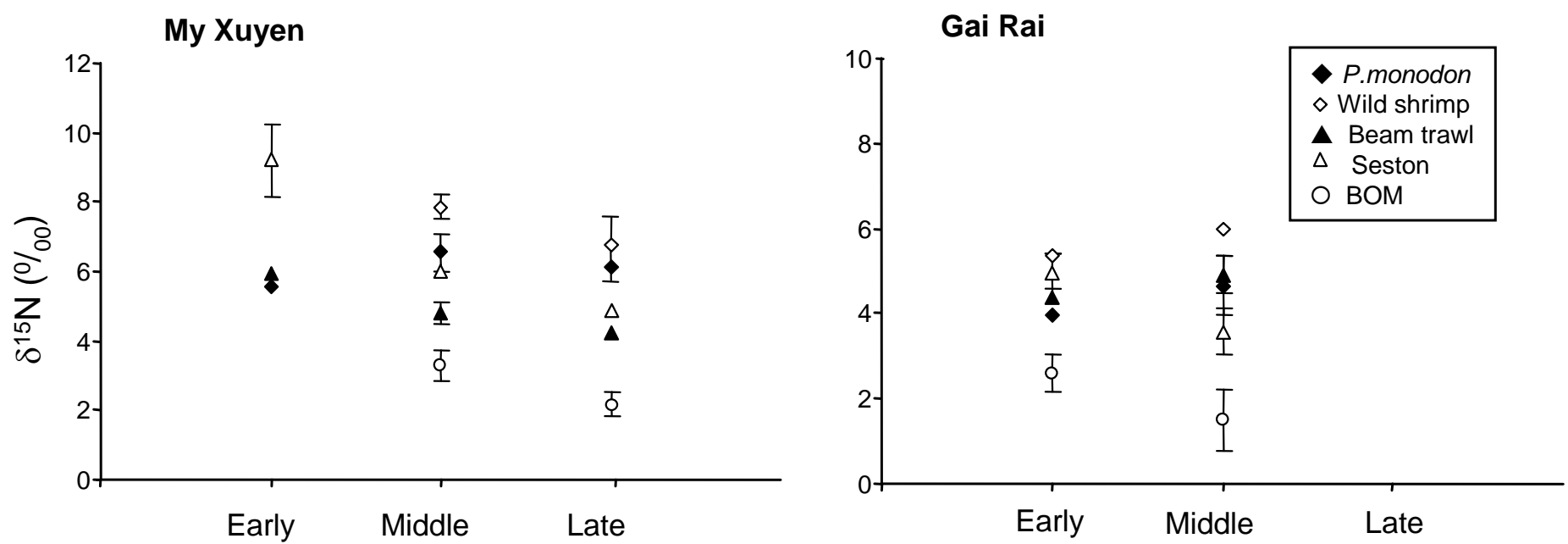


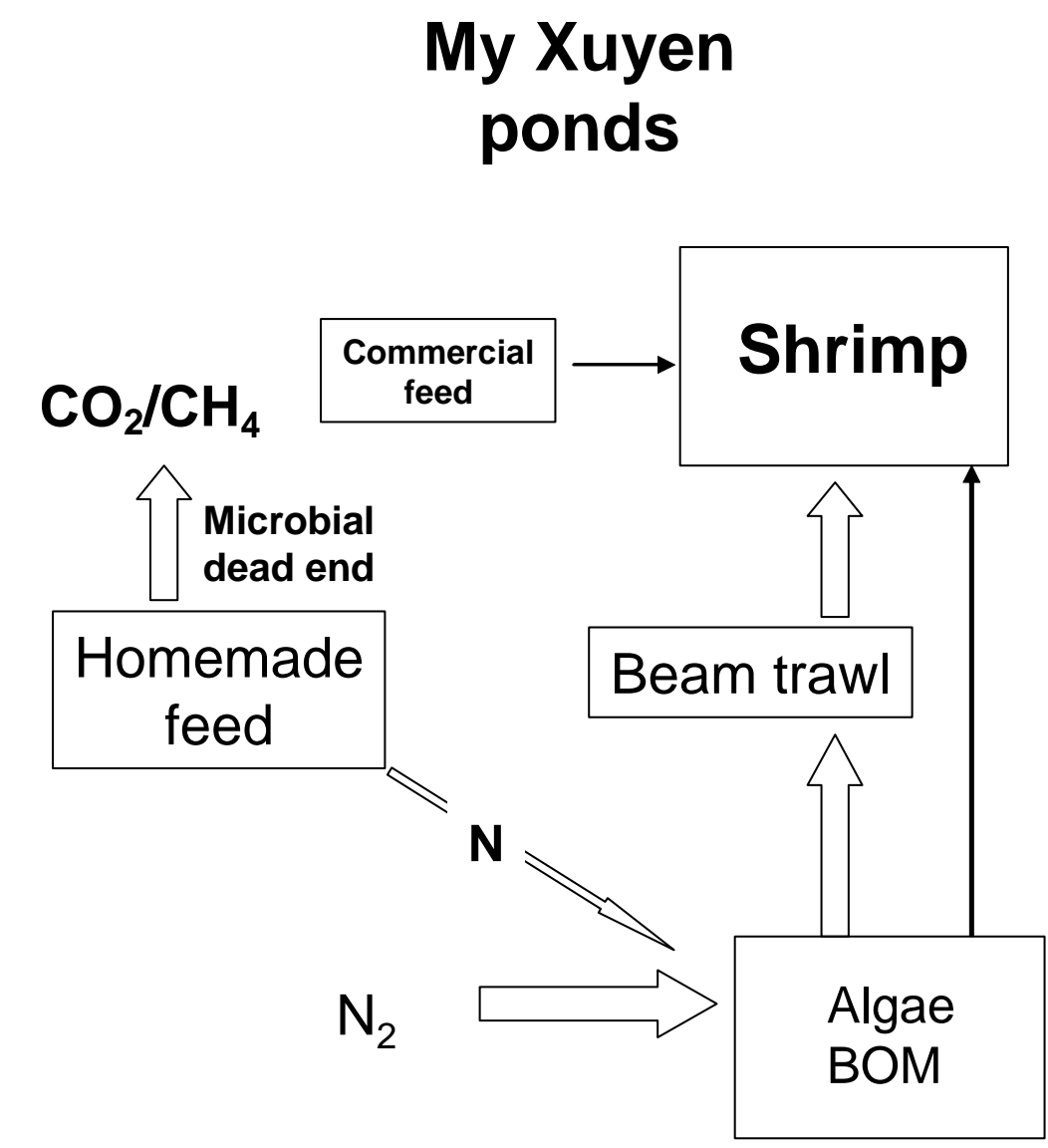

\section{Gia Rai ponds}

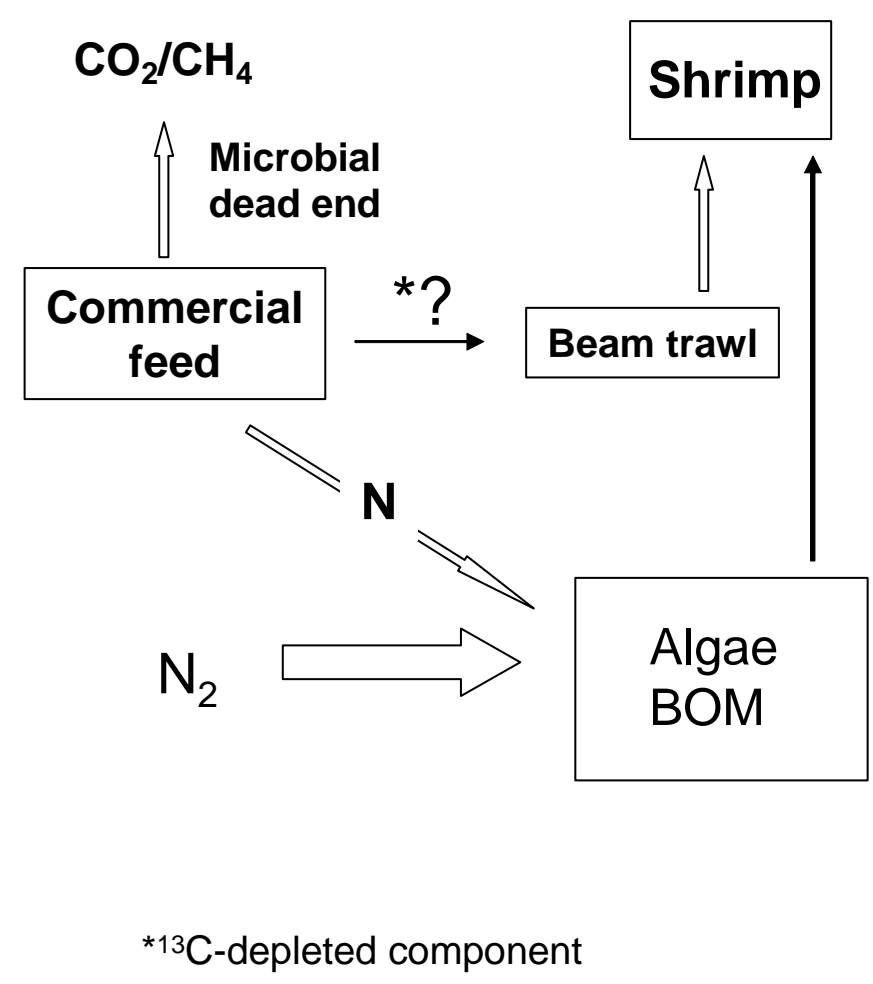


